\title{
Meta-Synthesis of Community Health Nursing Strategy
}

\author{
M. Agung Akbara*, Neti Juniartib, and Ahmad Yaminc \\ Community Health Nursing Department, Faculty of Nursing, Universitas Padjadjaran, \\ Bandung, West Java, Indonesia \\ amagungakbar24@gmail.com; bneti.juniarti@unpad.ac.id; cahmad.yamin@unpad.ac.id \\ *Correspondence: magungakbar24@gmail.com
}

Type of the Paper (Article)

Received: July 27, 2020; Accepted: August 16, 2020; Published: September 3, 2020

https://doi.org/10.29253/achnr.2020.23344

\begin{abstract}
Currently, Indonesia is facing growth and development problems that can lead to health vulnerability and risk of health problems in society. The role of community health nursing is the key to reducing health disparities that occur in society. Strengthening community health nurse strategies must be able to adapt to various settings so that the goals of community nursing care can be achieved optimally. The purpose of this meta-synthesis is to comprehensively understand and explore scientific evidence related to community health nursing strategies. Article review was conducted through several electronic databases including Science Direct, Ebsco Host, ProQuest, PubMed, and Google Scholar through the Indonesian National Library account. The keywords used are strategy, community health nursing OR public health nursing, and qualitative. Inclusion criteria include peer-reviewed articles, published in (2000-2020), and qualitative studies. The exclusion criteria are articles that are not in English, not in full text, and do not have a good article writing structure. This literature search found 7 articles analyzed. The findings of this study indicate that if self-nurse ability, quality nursing care, building partnership, health promotion strategy, and facing challenges have been identified through qualitative studies, they can be used as a strategy in the implementation of community health nursing. This study only discusses in quantity about community health nursing strategies. This requires further research on the quality of community nursing care to evaluate the strategies that have been implemented. The meta-synthesis review provides an interpretation of qualitative data to capture the essence of the phenomenon of interest regarding community health nursing strategies.
\end{abstract}

Keywords: community health nursing; strategy; meta-synthesis

\section{Introduction}

Currently, Indonesia is facing growth and development problems that can lead to health vulnerability and risk of health problems in society (Susanto, Bachtiar, \& Turwantoko, 2019). Increasing the role of community health nursing is the key to reducing health disparities that occur in the community to overcome these problems (Yoshioka Maeda, Katayama, Shiomi, \& Hosoya, 2018). Community health nursing has a responsibility to promote and improve public health. Through community health nursing can solve health problems in individuals, families, and communities that need community health services. 
This serves as the basis for the community health care system in developing community health management strategy (Markle-Reid et al., 2017).

The strategies developed must be able to optimize the impact of their work (Porr, 2015). Community health nursing performance must be supported by sufficient knowledge of determinant factors of health, able to work with clients, and be able to understand the importance of diversity to work together in overcoming health problems in society. (Evans-Agnew, Reyes, Primomo, Meyer, \& MatlockHightower, 2017). In the end, community health nursing can provide a service that supports and guides the public towards a healthier lifestyle (Akbar, 2019).

Community nurses provide public health services that can carry out disease prevention, health promotion, management, and care in various settings in the community (Melo \& Alves, 2019). The focus of community health nursing interventions in the public health service system includes health promotion (education, counseling, and community mobilization), disease prevention (health risk assessment, screening), disease management (case management, care coordination, patient monitoring, and rehabilitation), and policy management (WHO, 2017).

The strategies developed must be able to adapt to various settings so that the goals of community nursing care can be achieved optimally (Richardson \& Eick, 2014). Nursing care programs are an integral part of community-based health care. An important phase in implementing nursing care services is to understand the standards of the nursing process starting from assessment, formulating nursing diagnoses, developing nursing plans, implementing, and evaluating (Susanto et al., 2019). To evaluate how community health nursing is, it is necessary to consider program evaluation in aligning the nursing care program that will be developed next (Song \& Tang, 2019).

In addition, community health nursing strategies can also manage public health by addressing the gap between public health needs and available health services (Swider, Krothe, Reyes, \& Cravetz, 2013; Yoshioka-Maeda et al., 2006). Increasing the accessibility of health services their need in the community by expanding the geographic coverage of nursing services. However, the most important thing in the provision of nursing services must be accompanied by excellent quality nursing care. Therefore, community-based nursing services provide great opportunities for nurses to increase Universal Health Coverage (Chan, Fung, \& Chan, 2017).

Therefore, nursing has a large contribution compared to other health professions because of its role in health care management. Community health nursing through an integrated teaching-servicecommunity strategy can provide innovation, take important positions, integrated care, and through partnerships. In health services, nurses are recognized as professionals because they have the knowledge, abilities and skills that are able to promote integrated care by interacting with individuals, families and communities. (Souza, Seixas, David, \& Costa, 2017).

Some of the research on community health nursing strategies available in the literature such as community health nurses must have a broad vision of health, be able to reflect on and learn from experience, engage in appropriate pedagogical practice (M. A. Mabhala, 2013). Qualitative research on community health nursing strategies was conducted by Salgueiro, et al., (2013) who get if home visits can be used as an instrument in health promotion. Although some qualitative research literature on community health nursing strategies is available, further study is needed to clarify this phenomenon.

This study was conducted using a meta-synthesis of qualitative studies of community health nursing strategies. The aim of this study was to synthesize the qualitative research available in the literature on community health nursing strategies that can be used in community nursing practice.

\section{Methodology}

This literature review aims to comprehensively understand and explore scientific evidence related to community health nursing strategies. Therefore, analysis using the synthesis method was identified as a suitable methodology. Meta-synthesis can provide a good analytical and process analysis in combining the findings of qualitative research by comparing, compiling, and describing common themes as well as a deep understanding of the phenomenon (Campbell et al., 2011).

Meta-synthesis consists of three steps, consisting of 1) identifying relevant articles, 2) performing critical appraisal and data extraction, and 3) analyzing and analyzing findings. Article review was conducted through several electronic databases including Science Direct, Ebsco Host, ProQuest, PubMed, and Google Scholar through the Indonesian National Library account. The keywords used are strategy, 
community health nursing OR public health nursing, and qualitative. Inclusion criteria include peerreviewed articles, published in 2000-2020, and qualitative studies. The exclusion criteria are articles that are not in English, not in full text, and do not have a good article writing structure (Figure 1).

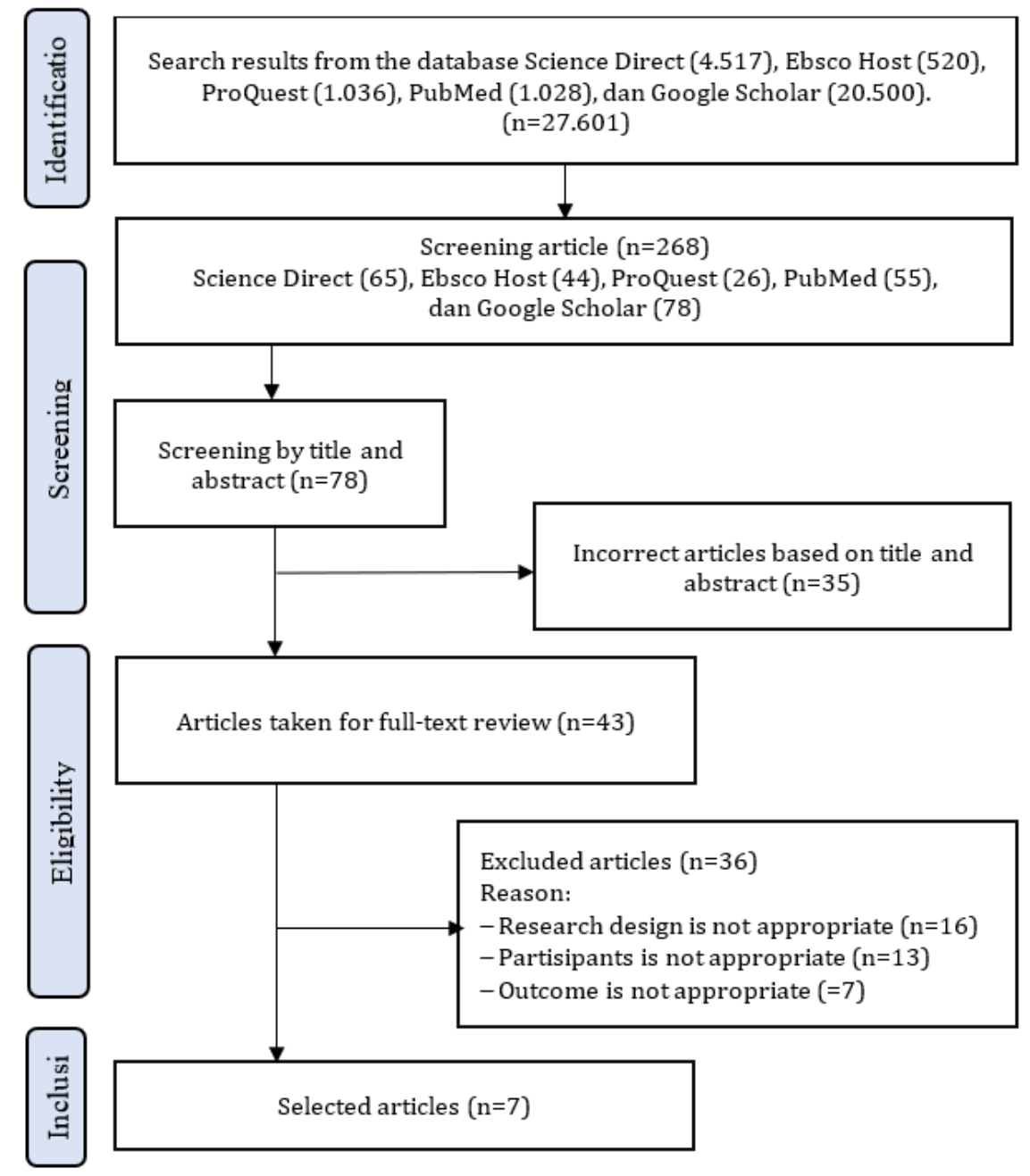

Figure 1. Flowchart of PRISMA method article search results.

This literature search found 27601 articles obtained from the database. After sorting the selected article titles according to the inclusion and exclusion criteria of Science Direct 65 articles, Ebsco Host 44 articles, ProQuest 26 articles, PubMed 55 articles, and Google Scholar 78 articles. Then, the next step is to sort the article content that has a good article structure and then skimming and scanning it so that from the 268 articles, 7 articles will be analyzed.

\section{3. $\quad$ Result}

Articles that have been selected according to the inclusion criteria are then read and summarized. Qualitative research on community health nursing strategies has not been widely carried out in the world. As far as the researcher knows, obtained from database searches, there are 7 articles that are relevant to the desired topic. The descriptive characteristics of the research articles in this literature review are described in the Table 1. 
Table 1. Descriptive characteristics of selected articles.

\begin{tabular}{|c|c|c|c|c|c|c|}
\hline No & Author (Year) & Country & Participant & Methodology & Analysis & $\begin{array}{c}\text { Data } \\
\text { Collection }\end{array}$ \\
\hline 1 & $\begin{array}{l}\text { Aston, Meagher- } \\
\text { Stewart, } \\
\text { Edwards, and } \\
\text { Young (2009) }\end{array}$ & Canada & $\begin{array}{l}\text { Community } \\
\text { health } \\
\text { nursing } \\
(\mathrm{n}=43)\end{array}$ & $\begin{array}{l}\text { interpretive } \\
\text { qualitative } \\
\text { studies }\end{array}$ & $\begin{array}{l}\text { Thematically } \\
\text { analysis }\end{array}$ & $\begin{array}{l}\text { semi-structured } \\
\text { interviews } \\
\text { 1. individual } \\
\text { 2. focus group }\end{array}$ \\
\hline 2 & Okura (2019) & Japan & $\begin{array}{l}\text { Community } \\
\text { health } \\
\text { nursing } \\
(n=29)\end{array}$ & $\begin{array}{l}\text { Modified } \\
\text { Grounded } \\
\text { theory } \\
\text { Approach (M- } \\
\text { GTA) }\end{array}$ & $\begin{array}{l}\text { Constant } \\
\text { comparative } \\
\text { analysis }\end{array}$ & $\begin{array}{l}\text { semi-structured } \\
\text { interviews }\end{array}$ \\
\hline 3 & $\begin{array}{l}\text { Markham and } \\
\text { Carney (2008) }\end{array}$ & Ireland & $\begin{array}{l}\text { Community } \\
\text { health } \\
\text { nursing }(n=8)\end{array}$ & qualitative & $\begin{array}{l}\text { Content } \\
\text { analysis }\end{array}$ & $\begin{array}{l}\text { semi-structured } \\
\text { interviews }\end{array}$ \\
\hline 4 & $\begin{array}{l}\text { Hörnsten, } \\
\text { Lindahl, } \\
\text { Persson, and } \\
\text { Edvardsson } \\
(2014)\end{array}$ & Sweden & $\begin{array}{l}\text { Community } \\
\text { health } \\
\text { nursing } \\
(n=10)\end{array}$ & qualitative & $\begin{array}{l}\text { Content } \\
\text { analysis }\end{array}$ & $\begin{array}{l}\text { in-depth } \\
\text { interviews }\end{array}$ \\
\hline 5 & $\begin{array}{l}\text { M.A Mabhala } \\
(2013)\end{array}$ & English & $\begin{array}{l}\text { Community } \\
\text { health } \\
\text { nursing } \\
(n=23)\end{array}$ & qualitative & $\begin{array}{l}\text { Comparative } \\
\text { analysis }\end{array}$ & $\begin{array}{l}\text { in-depth semi- } \\
\text { structured } \\
\text { interviews }\end{array}$ \\
\hline 6 & $\begin{array}{l}\text { Jucelia Salgueiro } \\
\text { et al. (2013) }\end{array}$ & Brazil & $\begin{array}{l}\text { Nurse in } \\
\text { primary care } \\
(n=9)\end{array}$ & $\begin{array}{l}\text { qualitative } \\
\text { descriptive }\end{array}$ & $\begin{array}{l}\text { Content } \\
\text { analysis }\end{array}$ & $\begin{array}{l}\text { semi-structured } \\
\text { interviews }\end{array}$ \\
\hline 7 & Mabhala (2015) & English & $\begin{array}{l}\text { Community } \\
\text { health } \\
\text { nursing } \\
(\mathrm{n}=26)\end{array}$ & $\begin{array}{l}\text { constructivist } \\
\text { grounded } \\
\text { theory (CGT). }\end{array}$ & $\begin{array}{l}\text { Constant } \\
\text { comparative } \\
\text { analysis }\end{array}$ & $\begin{array}{l}\text { semi-structured } \\
\text { interviews }\end{array}$ \\
\hline
\end{tabular}

Community health nursing interventions in the form of health promotion, disease prevention, disease management, and policy management are a strategy to address current trends in improving global health status. Community health nursing can make a significant contribution in meeting today's global health challenges (WHO, 2017). The articles selected for meta synthesis consist of 7 articles which are presented in the Table 2 .

\section{Discussion}

Meta-synthesis allows reinterpretation of qualitative data to capture the essence of the phenomenon of interest (Venning, Eliott, Wilson, \& Kettler, 2008). Several research results related to community health nursing strategies indicate several themes that can be carried out by community nurses as proven in the research as described in the following subsection.

\section{Self-Nurse Ability}

The results of several qualitative studies highlight that community health nursing plays a major role in addressing health disparities that occur in society. This needs to be supported by the presence of nurses' self-ability in carrying out nursing care, namely by building confidence and skills (Aston et al., 2009), able to reflect on and learn from experience (M.A Mabhala, 2013), have a keen interest in performing tasks, and are able to provide supervision to the community (Okura, 2019).

Another nurse's self-ability that needs to be considered is that nurses can be involved in empowering educational strategies and nurses can work in a health promotion perspective (Aston et al., 2009). The findings of this meta-synthesis also highlight that nurses must have a broad vision of health in the form of inequality in health, socio-economic factors, and political policies. (M.A Mabhala, 2013). Self-development of nurses is important to respond to various challenges currently in the community. Until finally, the involvement of nurses in the public health agenda is an inseparable part of intervening in public health disparities. 
Table 2. Study findings from selected articles.

\begin{tabular}{|c|c|c|}
\hline No & Author (year) & Findings \\
\hline 1 & Aston et al. (2009) & $\begin{array}{l}\text { Build capacity for partnership and community control } \\
\text { 1. Working from a community health promotion } \\
\text { perspective } \\
\text { 2. Build a trusting relationship } \\
\text { 3. Build confidence and skills } \\
\text { 4. Involved in empowering educational strategies } \\
\text { 5. Connect on a wider social network } \\
\text { 6. Facilitating obstacles faced by the community }\end{array}$ \\
\hline 2 & Okura (2019) & $\begin{array}{l}\text { Subjective Phenomena: } \\
\text { 1. Have a greater interest than their duty to provide } \\
\text { supervision to the community } \\
\text { 2. frequently visit the community for which they are } \\
\text { responsible } \\
\text { 3. Using the five senses to understand the relationship } \\
\text { between health and life in the community } \\
\text { 4. Learn from stakeholders } \\
\text { Objective Phenomena: } \\
\text { 1. Consider those who do not seek help from others } \\
\text { 2. Conduct and evaluate clinical practice }\end{array}$ \\
\hline & & $\begin{array}{l}\text { Core Category: Integration of collective agreements in } \\
\text { subjective and objective steps. }\end{array}$ \\
\hline 3 & $\begin{array}{l}\text { Markham and Carney } \\
(2008)\end{array}$ & $\begin{array}{l}\text { 1. Change of roles } \\
\text { 2. The components of quality nursing care } \\
\text { 3. Barriers to quality nursing care } \\
\text { 4. Factors that facilitate the delivery of quality care }\end{array}$ \\
\hline 4 & Hörnsten et al. (2014) & $\begin{array}{l}\text { Community health nurses use a variety of strategies in the } \\
\text { dialogue about health and lifestyle that fall under five themes } \\
\text { 1. Coaching patients vs. force them; } \\
\text { 2. Adapting to the patient vs. directing the conversation; } \\
\text { 3. Inspire trust vs. instill fear; } \\
\text { 4. Motivating and supporting patients vs. demanding } \\
\text { responsibility; } \\
\text { 5. Introducing emotionally charged subjects or avoiding } \\
\text { them }\end{array}$ \\
\hline 5 & M.A Mabhala (2013) & $\begin{array}{l}\text { 1. Have a broad vision of health } \\
\text { - Inequality in health } \\
\text { - Socio-economic factors } \\
\text { - Political policy } \\
\text { 2. Reflect and learn from experience } \\
\text { - Change attitudes } \\
\text { - Transferring information } \\
\text { - Change behavior } \\
\text { 3. Engage in proper pedagogical practice } \\
\text { - Provide understanding } \\
\text { - Engage students in context, share experiences, and } \\
\text { facilitate dialogue }\end{array}$ \\
\hline 6 & $\begin{array}{l}\text { Jucelia Salgueiro et al. } \\
\text { (2013) }\end{array}$ & $\begin{array}{l}\text { 1. Home visits as an instrument for health promotion } \\
\text { 2. In practice, the dominant action is curative and does not } \\
\text { take into account the social context } \\
\text { 3. Home visits as a way of reorienting the care model and } \\
\text { implementing health promotion. }\end{array}$ \\
\hline 7 & Mabhala (2015) & $\begin{array}{l}\text { 1. Health inequality is a major issue } \\
\text { 2. Socio-economic determinants of health } \\
\text { 3. Nurses must be involved with policy and politics }\end{array}$ \\
\hline
\end{tabular}




\section{Quality Nursing Care}

Community health nursing has grown very significantly in recent years. This development must also go hand in hand with improving the quality of nursing care by providing innovation, active involvement, and a skilled ability to provide quality services (Markham \& Carney, 2008), conduct and evaluate clinical practice (Okura, 2019). This is used as the basis for a health strategy to obtain the health status of an individual or population related to quality of life (Mabhala, 2013).

In line with that, Markham and Carney (2008) said that community health nursing care needs require standardized interventions based on scientific evidence findings in carrying out action procedures in order to improve the quality of care by using an integrated multidisciplinary approach.. The findings of study by Markham and Carney (2008) also identified the need for nurses in the community and the support of public health nurses to provide quality nursing care.

\section{Building Partnerships}

One of the essences of community health nursing intervention is how to try to change the health behavior of an individual or community through partnership and empowerment of the community itself. The various strategies obtained in this meta-synthesis study are by building trusting relationships, connecting to a wider social network, and facilitating obstacles encountered in the community. The findings in this study find that the relationship between nurse-client and nurse-other health professionals becomes an important strategy in running the partnership (Aston et al., 2009).

Community health nurses recognize the importance of understanding good partnership relationships with the community. Through community visits and learning from stakeholders, stakeholders can understand the various characteristics of society by using the five senses in understanding the relationship between health and life in the community. This is a way to get a picture of the situation as a whole, both subjective and objective phenomena in the community (Okura, 2019).

\section{Health Promotion Strategy}

Communitty health nursing in conducting health promotion has a good capacity in providing motivation, understanding, and practice. Community health nursing process is able to reflect the nursing care provided to transfer information, change attitudes, and change behavior. Community health nursing is capable of developing strategies to provide appropriate education when providing understanding and engaging clients in dialogue (M.A Mabhala, 2013).

Strategies that can be used in health promotion are through home visits. Community nurses can use home visits as a good approach to providing health education and needs to individuals, families, and communities. Home visits can be used as a fundamental strategy in providing primary health care because they can develop actions aimed at health promotion. Home visits as a way of reorienting the care model and implementing health promotion (Jucelia Salgueiro et al., 2013). Thus, nurses will more often visit the community for which they are responsible (Okura, 2019).

Other findings in this meta-synthesis are that nurses can provide understanding, involve the community in the context, share experiences, and facilitate dialogue as the right strategy. (M.A Mabhala, 2013). Community nurses can use health promotion strategies through dialogue with the theme of guiding the patient, adapting to the patient, inspiring beliefs, motivating and supporting patients, and introducing emotionally charged or avoidant subjects (Hörnsten et al., 2014). This method becomes a means of increasing public knowledge and awareness in the context of health promotion.

\section{Facing Challenges}

The scope of community practice is a broad area in conducting nursing care and is a fundamental difference from the clinical practice area. The scope of community nursing practice is so broad that it will encounter many challenges. In practice implementation, Markham and Carney (2008) explained that there are several obstacles to providing quality nursing care. According to the research conducted by Mabhala (2015) hich states that health inequalities, socio-economic factors, policies, and politics are challenges facing nurses.

Research conducted by Markham and Carney (2008) discover if a change in roles related to services practice with technological advances which requires specialist nurses in community health nursing. 
Disease management in the community also requires a quality nursing care component by providing holistic services, standardized care, meeting client needs, good communication, and maintaining good relationships.

The results of this investigation in particular form the components of community nursing strategy through self-nurse ability, quality nursing care, building partnership, health promotion strategy, and facing challenges. Strengthening community health nursing strategies is an important foundation in the implementation of optimal nursing care by empowering community nurses in nursing care (Susanto et al., 2019). Through this, community health nurses can identify health problems that concern individuals, families, and communities that need to be resolved with health services and health policies. (Yoshioka Maeda et al., 2018). This study only discusses in quantity about community health nursing strategies. This requires further research on the quality of community nursing care to evaluate the strategies that have been implemented.

\section{Conclusion}

Meta-synthesis reviews obtain generalizable and implicable information in developing community health nursing strategies. The findings of this study show that if self-nurse ability, quality nursing care, building partnership, health promotion strategy, and facing challenges have been identified through qualitative studies, they can be used as a strategy in the implementation of community health nursing. It is recommended that health and education agencies develop community health nursing strategies to respond to health problems that are rapidly developing today.

\section{References}

Akbar, M. A. (2019). Buku Ajar Konsep-Konsep Dasar Dalam Keperawatan Komunitas. Yogyakarta: Deepublish.

Aston, M., Meagher-Stewart, D., Edwards, N., \& Young, L. M. (2009). Public health nurses' primary health care practice: strategies for fostering citizen participation. J Community Health Nurs, 26(1), 24-34. doi:10.1080/07370010802605762

Campbell, R., Pound, P., Morgan, M., Daker-White, G., Britten, N., Pill, R., .. . Donovan, J. (2011). Evaluating metaethnography: systematic analysis and synthesis of qualitative research. Health Technol Assess, 15(43), 1164. doi:10.3310/hta15430

Chan, W. Y., Fung, I. M., \& Chan, E. (2017). Universal Health Coverage through Community Nursing Services: China vs. Hong Kong. Rev Lat Am Enfermagem, 25, e2838. doi:10.1590/1518-8345.1664.2838

Evans-Agnew, R., Reyes, D., Primomo, J., Meyer, K., \& Matlock-Hightower, C. (2017). Community Health Needs Assessments: Expanding the Boundaries of Nursing Education in Population Health. Public Health Nurs, 34(1), 69-77. doi:10.1111/phn.12298

Hörnsten, Å., Lindahl, K., Persson, K., \& Edvardsson, K. (2014). Strategies in health-promoting dialogues - primary healthcare nurses' perspectives - a qualitative study. 28(2), 235-244. doi:10.1111/scs.12045

Salgueiro, J. N., Laís de Miranda Crispim, C., dos Santos, R. M., \& Danielly Santos dos, A. (2013). Home visits as a strategy for health promotion by nursing. Revista Brasileira em Promocao da Saude, 26(4), 513-522. doi: $10.5020 / 3116$

Mabhala, M. A. (2013). Health inequalities as a foundation for embodying knowledge within public health teaching: a qualitative study. Int J Equity Health, 12, 46. doi:10.1186/1475-9276-12-46

Mabhala, M. A. (2015). Public health nurse educators' conceptualisation of public health as a strategy to reduce health inequalities: a qualitative study. International Journal for Equity in Health, 14(1), 14. doi:10.1186/s12939015-0146-2

Markham, T., \& Carney, M. (2008). Public Health Nurses and the delivery of quality nursing care in the community. $J$ Clin Nurs, 17(10), 1342-1350. doi:10.1111/j.1365-2702.2006.01894.x

Markle-Reid, M., Dykeman, C., Ploeg, J., Kelly Stradiotto, C., Andrews, A., Bonomo, S., ... Salker, N. (2017). Collaborative leadership and the implementation of community-based fall prevention initiatives: a multiple case study of public health practice within community groups. BMC Health Serv Res, 17(1), 141. doi:10.1186/s12913017-2089-3

Melo, P., \& Alves, O. (2019). Community Empowerment and Community Partnerships in Nursing Decision-Making. Healthcare, 7(2), 1-8. doi:10.3390/healthcare7020076

Okura, M. (2019). The Process of Structuring Community Health Needs by Public Health Nurses Through Daily Practice: A Modified Grounded Theory Study. Asian Nurs Res (Korean Soc Nurs Sci), 13(4), 229-235. doi:10.1016/j.anr.2019.08.001 
Porr, C. J. (2015). Important interactional strategies for everyday public health nursing practice. Public Health Nurs, 32(1), 43-49. doi:10.1111/phn.12097

Richardson, G., \& Eick, S. A. (2014). English health visitors' perceptions of conducting indoor environmental assessments: barriers and facilitators. Public Health Nurs, 31(4), 336-343. doi:10.1111/phn.12077

Song, P., \& Tang, W. (2019). The community-based integrated care system in Japan: Health care and nursing care challenges posed by super-aged society. Biosci Trends, 13(3), 279-281. doi:10.5582/bst.2019.01173

Souza, K. M. J. d., Seixas, C. T., David, H. M. S. L., \& Costa, A. Q. d. (2017). Contributions of Public Health to nursing practice. J Revista Brasileira de Enfermagem, 70(3), 543-549. doi:10.1590/0034-7167-2016-0401

Susanto, T., Bachtiar, S., \& Turwantoko. (2019). Performance of Public Health Nurses And Coverage of The Nursing are Program By Community Health Centers in Jember Indonesia. IJCBNM, 7(2), 161-168. doi:10.30476/IJCBNM.2019.44887

Swider, S. M., Krothe, J., Reyes, D., \& Cravetz, M. (2013). The Quad Council practice competencies for public health nursing. Public Health Nurs, 30(6), 519-536. doi:10.1111/phn.12090

Venning, A., Eliott, J., Wilson, A., \& Kettler, L. (2008). Understanding young peoples' experience of chronic illness: a systematic review. Int J Evid Based Healthc, 6(3), 321-336. doi:10.1111/j.1744-1609.2008.00107.x

WHO. (2017). Enhacing The Role of Community Health Nursing For Universal Health Coverage. Geneva: WHO Press.

Yoshioka-Maeda, K., Taguchi, A., Murashima, S., Asahara, K., Anzai, Y., Arimoto, A., . . Magilvy, J. K. (2006). Function and practice of public health nursing in Japan: a trial to develop the Japanese Purpose-Focused Public Health Nursing Model. J Nurs Manag, 14(6), 483-489. doi:10.1111/j.1365-2934.2006.00688.x

Yoshioka Maeda, K., Katayama, T., Shiomi, M., \& Hosoya, N. (2018). Educational program for middle-level public health nurses to develop new health services regarding community health needs: protocol for a randomized controlled trial. BMC Nursing, 17(1), 18. doi:10.1186/s12912-018-0287-x 